\title{
Enumeration and Characterization of Nitrogen-Fixing Bacteria in an Eelgrass (Zostera marina) Bed
}

\author{
Wung Yang Shieh,, ${ }^{1, *}$ Usio Simidu, ${ }^{1}$ and Yoshiharu Maruyama ${ }^{2}$ \\ ${ }^{1}$ Ocean Research Institute, University of Tokyo, Nakano, Tokyo 164; and 2Department of \\ Agricultural Chemistry, Faculty of Agriculture, University of Tokyo, Bunkyo, \\ Tokyo 113, Japan
}

\begin{abstract}
Marine nitrogen-fixing bacteria distributed in the eelgrass bed and seawater of Aburatsubo Inlet, Kanagawa, Japan were investigated using anaerobic and microaerobic enrichment culture methods. The present enrichment culture methods are simple and efficient for enumeration and isolation of nitrogen-fixing bacteria from marine environments. Mostprobable-number (MPN) values obtained for nitrogen-fixing bacteria ranged from $1.1 \times 10^{2}$ to $4.6 \times 10^{2} / \mathrm{ml}$ for seawater, $4.0 \times 10^{4}$ to $4.3 \times 10^{5} / \mathrm{g}$ wet wt for eelgrass-bed sediment, and $2.1 \times 10^{5}$ to $1.2 \times 10^{7} / \mathrm{g}$ wet wt for eelgrass-root samples. More than 100 strains of halophilic, nitrogen-fixing bacteria belonging to the family Vibrionaceae were isolated from the MPN tubes. These isolates were roughly classified into seven groups on the basis of their physiological and biochemical characteristics. The majority of the isolates were assigned to the genus Vibrio and one group to the genus Photobacterium. However, there was also a group that could not be identified to the generic level. All isolates expressed nitrogen fixation activities under anaerobic conditions, and no organic growth factors were required for their activities.
\end{abstract}

\section{Introduction}

For many years, biological nitrogen fixation occurring in marine environments was believed to be mainly due to cyanobacteria [37]. However, the presence of bacterial nitrogen fixation has been demonstrated in many diverse marine habitats since the 1970s. Most environments where bacterial nitrogen fixation has been found are benthic, such as seagrass $[5,6,27,36]$, salt marsh $[26,28]$, mangrove [15, 43, 44], and coral reef [41] communities, and a variety of estuarine and marine sediments $[14,16,23]$. There are also reports that bacterial nitrogenase activity is associated with diatoms and other plankters in the pelagic zone [19, 21]. It also has been demonstrated that heterotrophic nitrogen fixation might occur in association with oxygen-poor microzones in nitrogen-depleted

\footnotetext{
* Present address: Institute of Oceanography, National Taiwan University, P.O. Box 23-13, Taipei, Taiwan, Republic of China.
} 
aerobic marine waters $[24,25]$. These studies indicate that nitrogen-fixing bacteria may introduce significant amounts of ammonium nitrogen into various marine environments.

Several studies have been done concerning the enumeration of nitrogenfixing bacteria in seawater $[10,21,42]$, estuarine and oceanic sediments [20, $21]$, and salt marsh soils $[8,28]$. Nitrogen-fixing bacteria associated with the roots of marsh grass Spartina alterniflora and the gastrointestinal tracts of sea urchins have also been enumerated [11,28]. Early attempts were made using plate counts [21, 42]. However, these methods proved to be ineffective because many strains isolated from agar media without added combined nitrogen proved to be nitrogen-scavenging bacteria that were unable to fix nitrogen when assayed by the acetylene reduction method [17]. The most-probable-number (MPN) counts of nitrogen-fixing bacteria have also been done by analyzing nitrogenase (acetylene reduction) activity in the cultures that were inoculated with $0.2 \mu \mathrm{m}$ filters used to concentrate the bacteria in the initial seawater samples [10]. However, only low numbers of nitrogen-fixing bacteria were counted in these studies. For example, counts of $10^{-1}-10^{2}$ cells/liter for seawater from Chesapeake Bay and the coast of Puerto Rico were reported by Guerinot and Colwell [10]. Nitrogen-fixing bacteria requiring $\mathrm{NaCl}$ for growth have been isolated from a variety of marine sources $[10,22,39,40]$. However, nitrogenase activity of these bacteria was low, and few of them showed significant levels of nitrogenase activity (>10 nmol $\mathrm{C}_{2} \mathrm{H}_{4} / \mathrm{mg}$ dry wt cells/hour) within a few hours of incubation.

During a study of nitrogen fixation in an eelgrass bed in Aburatsubo Inlet, Kanagawa, Japan, we isolated a species of marine nitrogen-fixing Vibrio from eelgrass (Zostera marina) roots using an anaerobic enrichment culture method [32]. This bacterium showed rapid growth in a nitrogen-free liquid medium and it expressed nitrogenase activity after only a few hours of incubation under anaerobic conditions. In the present study, anaerobic and microaerobic enrichment culture methods, basically similar to that of our previous report [32], were applied in the MPN technique for further enumeration and isolation of marine nitrogen-fixing bacteria distributed in the eelgrass bed and seawater of Aburatsubo Inlet. More than 100 strains of marine nitrogen-fixing bacteria were isolated from eelgrass roots, eelgrass-bed sediment, and seawater. Their taxonomic characteristics and nitrogen fixation properties were also examined.

\section{Materials and Methods}

\section{Sample Collection and Treatment}

Samples of sediment and eelgrass roots were collected from an eelgrass bed in Aburatsubo Inlet, Kanagawa, Japan, in July and August of 1986, and seawater samples were collected from two stations located in this inlet in June and August of 1987. All samples were processed within a few hours. After root samples were washed free of sediment in sterile seawater, $1 \mathrm{~g}$ wet wt samples of the roots were washed once again by vigorous shaking in $50 \mathrm{ml}$ of sterile seawater containing 1 ppm Tween 80 (root rinse water). The roots were again washed three times in sterile seawater, and then homogenized with $9 \mathrm{ml}$ of sterile seawater (root homogenate solution). Samples of seawater, sediment, root rinse water, and root homogenate solution were then used for bacterial counts. 


\section{Media}

To determine suitable carbon sources for obtaining the most active nitrogen-fixing bacteria, we examined 10 sugars and organic acids for their effects on the nitrogenase activities associated with eelgrass roots and eelgrass-bed sediment. Glucose and sucrose were most effective in enhancing the activities (data not shown). They were therefore used as the carbon sources in making nitrogenfree ( $\mathrm{N}$-free) and nitrogen-deficient ( $\mathrm{N}$-deficient) media for enrichment of nitrogen-fixing bacteria. The $\mathrm{N}$-free liquid media contained the following components: (1) basal medium $\left(\mathrm{NaCl} 28 \mathrm{~g}, \mathrm{MgSO}_{4}\right.$. $7 \mathrm{H}_{2} \mathrm{O} 5 \mathrm{~g}, \mathrm{CaCl}_{2} \cdot 2 \mathrm{H}_{2} \mathrm{O} 10 \mathrm{mg}, \mathrm{Na}_{2} \mathrm{MoO}_{4} \cdot 2 \mathrm{H}_{2} \mathrm{O} 10 \mathrm{mg}$, Tris $50 \mathrm{mmol}$, distilled water $800 \mathrm{ml}$ ) adjusted to $\mathrm{pH} 8.0 ;(2) \mathrm{K}_{2} \mathrm{HPO}_{4} 0.5 \mathrm{~g}$ dissolved in $100 \mathrm{ml}$ of distilled water; and (3) glucose or sucrose $5 \mathrm{~g}, \mathrm{FeCl}_{3} \cdot 6 \mathrm{H}_{2} \mathrm{O} 15 \mathrm{mg}$ dissolved in $100 \mathrm{ml}$ of distilled water. These were mixed after autoclaving separately. The $\mathrm{N}$-deficient liquid media were prepared by supplementing $\mathrm{N}$-free liquid media with $1 \mathrm{mg}$ of yeast extract (Difco) per liter. The polypepton-yeast-glucose agar (PYG-A) medium contained the following two components: (1) Polypepton (Daigo, Tokyo, Japan) $2.0 \mathrm{~g}$, yeast extract (Difco, Detroit, Michigan, USA) $0.5 \mathrm{~g}$, Tris $50 \mathrm{mmol}$, and agar (Difco) $15 \mathrm{~g}$ dissolved in $900 \mathrm{ml}$ of seawater and adjusted to $\mathrm{pH} 7.6$; (2) $5 \mathrm{~g}$ glucose dissolved in $100 \mathrm{ml}$ of distilled water. The two components were mixed after autoclaving separately. The polypepton-yeast agar (PY-A) medium contained $2.0 \mathrm{~g}$ Polypepton (Daigo), $0.5 \mathrm{~g}$ yeast extract (Difco), and $15 \mathrm{~g}$ agar (Difco) in 1 liter of $90 \%$ seawater, adjusted to $\mathrm{pH} 7.6$.

\section{Bacterial Enumeration}

One milliliter seawater, $1 \mathrm{~g}$ wet wt sediment, $1 \mathrm{ml}$ root rinse water, and $1 \mathrm{ml}$ root homogenate solution were serially diluted with $9 \mathrm{ml}$ of sterile seawater. Plate counts of heterotrophic bacteria were done by spreading $0.1 \mathrm{ml}$ aliquots of each dilution onto duplicate PY-A or PYG-A plates. Incubation was carried out at $25^{\circ} \mathrm{C}$ for 7 days under either aerobic (air) or anaerobic (GasPak System, BBL, Cockeysville, Maryland, USA) conditions. The PY-A and PYG-A media were used for aerobic and anaerobic cultures, respectively. The most-probable-number (MPN) of heterotrophic bacteria in seawater and nitrogen-fixing bacteria in all samples was estimated from series with three tubes per dilution using the tables of Cochran [7]. For heterotrophic bacteria, $1 \mathrm{ml}$ aliquots of each diluent were added to $5 \mathrm{ml}$ of PY broth (PY-B) medium and incubated at $25^{\circ} \mathrm{C}$ for 7 days under aerobic conditions. For nitrogen-fixing bacteria, a $1 \mathrm{ml}$ aliquot of each diluent was transferred to a $20 \mathrm{ml}$ test tube containing $5 \mathrm{ml}$ of each of the following liquid media: (1) $\mathrm{N}$-free glucose (NFG), (2) N-deficient glucose (NDG), (3) N-free sucrose (NFS), (4) N-deficient sucrose (NDS). After the tubes were sealed with rubber stoppers, the air in each tube was replaced with $\mathrm{N}_{2}(100 \%)$ or $\mathrm{N}_{2} / \mathrm{O}_{2}(97 \%: 3 \%)$. All cultures were incubated in the dark at $25^{\circ} \mathrm{C}$ for $3-7$ days. The criterion used to record an MPN tube as positive was the development of visible turbidity because nonnitrogen-fixing bacteria (usually oligotrophic bacteria) might develop invisible (but never visible) turbidity in the present $\mathrm{N}$-free or $\mathrm{N}$-deficient media.

\section{Isolation of Nitrogen-Fixing Bacteria}

MPN tubes that developed visible turbidity were again serially diluted with solution containing $25 \mathrm{~g} \mathrm{NaCl}$ and $5 \mathrm{~g} \mathrm{MgSO}_{4}-7 \mathrm{H}_{2} \mathrm{O}$ in 1 liter of distilled water. A $0.1 \mathrm{ml}$ aliquot of each diluent of the cultures was transferred to fresh $\mathrm{N}$-free or $\mathrm{N}$-deficient medium and the anaerobic or microaerobic enrichment culture procedures described above were repeated. For the final isolation of nitrogen-fixing bacteria, the cultures of the highest dilution with positive growth from the second enrichment were spread on PY-A plates and the plates were incubated at $25^{\circ} \mathrm{C}$ for $2-5$ days under aerobic conditions. All colonies from the plating of the same enrichment culture were usually of the same type, indicating that they might have been derived from the same cell. However, two types of colonies also occurred on some of the plates. Individual colonies were picked and purified by repeated streakings on PY-A plates. The nitrogenase activity of the isolates was measured by the acetylene-reduction assay method. A variety of marine nitrogen-fixing bacteria were isolated using the present enrichment culture methods. 


\section{Measurement of Nitrogenase Activity}

The nitrogenase activity of the isolates was measured by the acetylene-reduction assay method using a Shimadzu G-4CM gas chromatograph [32]. Cells from PY-A plates were inoculated into $20 \mathrm{ml}$ tubes containing $5 \mathrm{ml} \mathrm{NFG}$ medium. The air in the tube was replaced with $\mathrm{N}_{2}(100 \%)$ or $\mathrm{N}_{2} / \mathrm{O}_{2}(97 \%: 3 \% ; \mathrm{v} / \mathrm{v})$ after it was sealed with a rubber stopper. Incubation was carried out at $25^{\circ} \mathrm{C}$ in the dark. The tubes that developed turbidities (optical density at $600 \mathrm{~nm}$ ) of $0.10-0.20$ were injected with $2 \mathrm{ml}$ of acetylene with a gas-tight syringe. Incubation was continued for a day, and then $0.2 \mathrm{ml}$ of gas in each tube was removed with a gas-tight syringe for the analysis of ethylene production.

\section{Characterization of Nitrogen-Fixing Isolates}

Characterization of the nitrogen-fixing isolates was carried out according to the methods described in our previous report [34] with some modifications. The presence of agarase was examined by incubating the isolates on PY agar plates for 5 days, and strains that caused liquefaction or depressions were recorded as agarase-positive. Some strains that showed ambiguous reactions in this test were clarified by the iodine test [1]. The ability to produce acid and gas from different carbohydrates was determined in stab media as described previously [34]. However, broth media free of agar were also used instead of stab media for some agar-degrading isolates which produced acid from agar [33]. Poly- $\beta$-hydroxybutyrate (PHB) accumulation was tested in a medium containing the following two components: (1) $0.5 \mathrm{~g}$ of yeast extract (Difco), and $50 \mathrm{mmol}$ Tris, dissolved in $900 \mathrm{ml}$ of seawater and adjusted to $\mathrm{pH} 8.0$; (2) $2 \mathrm{~g}$ of glucose dissolved in $100 \mathrm{ml}$ of distilled water. The two components were mixed after autoclaving separately. Growth at different concentrations of $\mathrm{NaCl}$ was determined in yeast extract $(0.4 \%$, w/v; Difco) broth containing $0,3,6$, and $10 \% \mathrm{NaCl}$.

\section{Results and Discussion}

\section{Bacterial Enumeration}

Tables 1 and 2 summarize the MPN counts of nitrogen-fixing bacteria as well as the plate counts of heterotrophic bacteria in the eelgrass bed and seawater samples. Nitrogen-fixing bacteria were found in all samples using the present anaerobic and microaerobic enrichment culture methods. The MPN values of nitrogen-fixing bacteria ranged from $1.1 \times 10^{2}$ to $4.6 \times 10^{2}$ for seawater (cells/ $\mathrm{ml}$ ) and $4.0 \times 10^{4}$ to $4.3 \times 10^{5}$ for eelgrass-bed sediment (cells/g wet wt). For eelgrass-root samples, these values (cells/g wet wt) ranged from $2.2 \times 10^{5}$ to $1.2 \times 10^{7}$ for root rinse water and $2.1 \times 10^{5}$ to $4.6 \times 10^{5}$ for root homogenate solution.

In the present study, halophilic bacteria positive in nitrogenase (acetylene reduction) activity were isolated from all the enrichment culture tubes that developed visible turbidity. Some cultures (ca. 10\%) used in the isolation of nitrogen-fixing bacteria were not pure and contained nonnitrogen-fixing bacteria. However, nitrogen-fixing bacteria always appeared as the predominant groups in these mixed cultures: colony-forming units (CFU) of nitrogen-fixing bacteria were always much higher than those of nonnitrogen-fixing bacteria. The results indicate that the present counting methods are indeed applicable for the evaluation of nitrogen-fixing bacteria in marine environments. Guerinot and Colwell [10] reported aerobic plate counts of heterotrophic bacteria in 
Table 1. MPN and plate counts of various bacterial groups in the eelgrass bed of Aburatsubo Inlet (cells/g wet wt sediment or root sample)

\begin{tabular}{|c|c|c|c|c|c|}
\hline \multirow[b]{2}{*}{$\begin{array}{l}\text { Bacterial group } \\
\text { and counting } \\
\text { method }\end{array}$} & \multirow[b]{2}{*}{$\begin{array}{l}\text { Month } \\
\text { (in 1986) }\end{array}$} & \multirow[b]{2}{*}{ Medium $^{a}$} & \multicolumn{3}{|c|}{ Bacterial counts } \\
\hline & & & Sediment & $\begin{array}{l}\text { Root rinse } \\
\text { water }\end{array}$ & $\begin{array}{c}\text { Root } \\
\text { homogenate } \\
\text { solution }\end{array}$ \\
\hline \multicolumn{6}{|c|}{ Plate counts of heterotrophs } \\
\hline Aerobic & July & PY-A & $2.2 \times 10^{7}$ & $3.4 \times 10^{7}$ & $2.6 \times 10^{7}$ \\
\hline Aerobic & Aug. & PY-A & $2.6 \times 10^{7}$ & $2.4 \times 10^{7}$ & $2.8 \times 10^{7}$ \\
\hline Anaerobic & July & PYG-A & $4.2 \times 10^{6}$ & $6.2 \times 10^{6}$ & $3.8 \times 10^{6}$ \\
\hline Anaerobic & Aug. & PYG-A & $2.5 \times 10^{6}$ & $5.5 \times 10^{6}$ & $2.8 \times 10^{6}$ \\
\hline \multicolumn{6}{|c|}{ MPN counts of $\mathrm{N}_{2}$-fixing bacteria } \\
\hline Anaerobic & July & NFS & $9.0 \times 10^{4}$ & $1.2 \times 10^{7}$ & $2.4 \times 10^{5}$ \\
\hline Anaerobic & July & NDS & $2.3 \times 10^{5}$ & $5.5 \times 10^{5}$ & $2.4 \times 10^{5}$ \\
\hline Anaerobic & Aug. & NFG & $9.0 \times 10^{4}$ & $4.6 \times 10^{5}$ & $4.3 \times 10^{5}$ \\
\hline Anaerobic & Aug. & NDG & $1.5 \times 10^{5}$ & $2.2 \times 10^{5}$ & $2.3 \times 10^{5}$ \\
\hline Microaerobic & July & NFS & $2.4 \times 10^{5}$ & $1.2 \times 10^{6}$ & $4.6 \times 10^{5}$ \\
\hline Microaerobic & July & NDS & $4.0 \times 10^{4}$ & $2.3 \times 10^{6}$ & $2.4 \times 10^{5}$ \\
\hline Microaerobic & Aug. & NFG & $9.0 \times 10^{4}$ & $2.2 \times 10^{5}$ & $2.1 \times 10^{5}$ \\
\hline Microaerobic & Aug. & NDG & $4.3 \times 10^{5}$ & $7.5 \times 10^{5}$ & $4.3 \times 10^{5}$ \\
\hline
\end{tabular}

a PY-A, PY agar medium; PYG-A, PYG agar medium; NFS, liquid N-free sucrose medium; NFG, liquid N-free glucose medium; NDS, liquid N-deficient sucrose medium; NDG, liquid N-deficient glucose medium

seawater from Chesapeake Bay (from $1.9 \times 10^{4}$ to $5.1 \times 10^{4}$ cells $/ \mathrm{ml}$ ) which were similar to those in Aburatsubo Inlet seawater (from $3.3 \times 10^{4}$ to $1.6 \times$ $10^{5}$ cells $/ \mathrm{ml}$; Table 2). However, in their study, the MPN values of nitrogenfixing bacteria for seawater samples collected from Chesapeake Bay (from $2 \times$ $10^{-3}$ to $1.05 \times 10^{-1}$ cells $/ \mathrm{ml}$ ) were far lower than those in Aburatsubo Inlet seawater (from $1.1 \times 10^{2}$ to $4.6 \times 10^{2}$ cells $/ \mathrm{ml}$ ) obtained here (Table 2 ). The relatively low MPN values they obtained may be expected because they used enrichment media containing $100 \mathrm{mg}$ of yeast extract per liter. Although the high amount of yeast extract might support more diverse species of nitrogenfixing bacteria, bacteria other than nitrogen-fixing bacteria might grow in these media much more rapidly to surpass the latter.

\section{Nitrogen Fixation Activity}

A total of 127 strains of nitrogen-fixing bacteria were isolated from the above sources. All these isolates reduced acetylene into ethylene under anaerobic conditions ( $>200 \mathrm{nmol} \mathrm{C}_{2} \mathrm{H}_{4} /$ culture/day). Most of the isolates showed significant levels of nitrogenase activity after only a few hours of incubation when using the previous measurement method [34]. All isolates grew in the NFG medium under $\mathrm{N}_{2}$. This indicates that they could fix $\mathrm{N}_{2}$ as the sole nitrogen source under anaerobic conditions, and no organic growth factors were required by these isolates. Some of the isolates have been demonstrated to be tolerant to low levels of oxygen [34], but none of them showed significant growth in this medium under air. On the other hand, all isolates grew in PYG medium under both aerobic (air) and anaerobic (GasPak System, BBL) conditions. These 
Table 2. MPN and plate counts of various bacterial groups in Aburatsubo Inlet seawater (cells/ml)

\begin{tabular}{|c|c|c|c|c|}
\hline \multirow{2}{*}{$\begin{array}{l}\text { Bacterial } \\
\text { group and } \\
\text { counting } \\
\text { method }\end{array}$} & \multirow{2}{*}{$\begin{array}{l}\text { Month } \\
\text { (in 1987) }\end{array}$} & \multirow[b]{2}{*}{ Medium $^{a}$} & \multicolumn{2}{|c|}{ Bacterial counting value in } \\
\hline & & & Station I & Station II \\
\hline \multicolumn{5}{|c|}{ Plate counts of heterotrophs } \\
\hline $\begin{array}{l}\text { Aerobic } \\
\text { Aerobic } \\
\text { Anaerobic } \\
\text { Anaerobic }\end{array}$ & $\begin{array}{l}\text { June } \\
\text { Aug. } \\
\text { June } \\
\text { Aug. }\end{array}$ & $\begin{array}{l}\text { PY-A } \\
\text { PY-A } \\
\text { PYG-A } \\
\text { PYG-A }\end{array}$ & $\begin{array}{l}1.6 \times 10^{5} \\
1.2 \times 10^{5} \\
1.3 \times 10^{4} \\
3.8 \times 10^{4}\end{array}$ & $\begin{array}{l}3.3 \times 10^{4} \\
6.0 \times 10^{4} \\
1.8 \times 10^{3} \\
2.5 \times 10^{3}\end{array}$ \\
\hline \multicolumn{5}{|c|}{ MPN counts of heterotrophs } \\
\hline $\begin{array}{l}\text { Aerobic } \\
\text { Aerobic }\end{array}$ & $\begin{array}{l}\text { June } \\
\text { Aug. }\end{array}$ & $\begin{array}{l}\text { PY-B } \\
\text { PY-B }\end{array}$ & $\begin{array}{l}2.3 \times 10^{5} \\
1.5 \times 10^{6}\end{array}$ & $\begin{array}{l}2.1 \times 10^{5} \\
7.5 \times 10^{5}\end{array}$ \\
\hline \multicolumn{5}{|c|}{ MPN counts of $\mathrm{N}_{2}$-fixing bacteria } \\
\hline $\begin{array}{l}\text { Anaerobic } \\
\text { Anaerobic }\end{array}$ & $\begin{array}{l}\text { June } \\
\text { Aug. }\end{array}$ & $\begin{array}{l}\text { NFG } \\
\text { NFG }\end{array}$ & $\begin{array}{l}2.4 \times 10^{2} \\
1.5 \times 10^{2}\end{array}$ & $\begin{array}{l}1.1 \times 10^{2} \\
4.6 \times 10^{2}\end{array}$ \\
\hline
\end{tabular}

a PY-A, PY agar medium; PYG-A, PYG agar medium; PY-B, PY broth medium; NFG, liquid $N$-free glucose medium

results indicate that all isolates were typical facultatively anaerobic, nitrogenfixing bacteria. Microaerophilic, nitrogen-fixing bacteria requiring $\mathrm{NaCl}$ for growth have been isolated from the gland of Deshayes in shipworms [39] and the roots of marsh grass Spartina alterniflora [22] in the past several years. However, none of these bacteria could be isolated using the present microaerobic culture methods. Some nitrogen-fixing bacteria isolated from the rhizosphere of terrestrial plants $[18,38]$ have been demonstrated to fix nitrogen only in the presence of combined nitrogen or certain vitamins but these bacteria were also unable to be isolated in this study. Considering the high MPN counts of facultatively anaerobic, nitrogen-fixing bacteria without the requirement of organic growth factors, these bacteria might be important in providing inputs of ammonium nitrogen into the present study sites. In our previous report [35], we suggested that the in situ nitrogenase activity of eelgrass rhizome-root complexes might be primarily attributed to root-associated nitrogen-fixing bacteria. We also suggested that facultatively anaerobic nitrogen-fixing bacteria, including the present isolates, might be the most important nitrogen fixers associated with eelgrass roots.

\section{Characterization of Nitrogen-Fixing Isolates}

All the nitrogen-fixing isolates were gram-negative rods which were motile by means of a single polar flagellum in PY-B medium. They fermented glucose and required $\mathrm{NaCl}$ for growth. These characteristics clearly indicate that all isolates belong to the family Vibrionaceae. All isolates were roughly divided into seven groups (Table 3), based mainly on the results of the following tests: PHB accumulation, utilization of $\beta$-hydroxybutyrate, and production of agarase, oxidase, catalase, and gas from glucose fermentation. 
Table 3. Characteristics of marine nitrogen-fixing bacteria isolated in this study

\begin{tabular}{|c|c|c|c|c|c|c|c|}
\hline $\begin{array}{l}\text { Bacterial group } \\
\text { (No. of strains) }\end{array}$ & $\begin{array}{c}I \\
(5)\end{array}$ & $\begin{array}{l}\text { II } \\
(4)\end{array}$ & $\underset{(10)}{\text { III }}$ & $\begin{array}{l}\text { IV } \\
(12)\end{array}$ & $\begin{array}{c}V \\
(73)\end{array}$ & $\begin{array}{c}\text { VI } \\
(15)\end{array}$ & $\begin{array}{l}\text { VII } \\
(8)\end{array}$ \\
\hline \multicolumn{8}{|l|}{ Characteristic } \\
\hline PHB accumulation & $+b$ & + & - & - & - & - & - \\
\hline Gas from glucose & - & - & - & - & - & - & + \\
\hline Agarase & - & - & + & + & - & - & - \\
\hline Catalase & + & + & + & + & + & + & - \\
\hline Oxidase & + & + & $\mathbf{v}$ & + & + & - & - \\
\hline Gelatinase & + & + & + & - & $\mathrm{v}$ & - & + \\
\hline Lecithinase & + & $\mathbf{v}$ & - & - & - & - & - \\
\hline Lipase & + & + & + & + & $\mathrm{v}$ & - & - \\
\hline Amylase & $\mathrm{v}$ & $\mathbf{v}$ & $\mathbf{w}$ & + & + & - & - \\
\hline DNAse & + & $\mathbf{v}$ & $\mathbf{w}$ & $\mathbf{v}$ & + & - & + \\
\hline Chitinase & $\mathbf{w}$ & - & - & - & - & - & - \\
\hline Arginine dihydrolase & + & $\mathbf{v}$ & - & - & $\mathbf{v}$ & - & - \\
\hline Sensitivity to $0 / 129^{\circ}(150 \mu \mathrm{g})$ & $\mathbf{v}$ & $\mathrm{v}$ & $\mathbf{v}$ & $\mathbf{v}$ & $\mathbf{v}$ & + & - \\
\hline \multicolumn{8}{|l|}{ Growth at } \\
\hline $4^{\circ} \mathrm{C}$ & $\mathbf{v}$ & $\mathbf{v}$ & $\mathrm{v}$ & - & $\mathbf{v}$ & $\mathbf{v}$ & - \\
\hline $20^{\circ} \mathrm{C}$ & + & + & + & + & + & + & + \\
\hline $40^{\circ} \mathrm{C}$ & - & $\mathbf{v}$ & $\mathrm{v}$ & $\mathbf{v}$ & $\mathbf{v}$ & $\mathbf{v}$ & + \\
\hline \multicolumn{8}{|l|}{ Growth in } \\
\hline $0 \% \mathrm{NaCl}$ & - & - & - & - & - & - & - \\
\hline $3 \% \mathrm{NaCl}$ & + & + & + & + & + & + & + \\
\hline $6 \% \mathrm{NaCl}$ & + & + & + & + & + & + & + \\
\hline $10 \% \mathrm{NaCl}$ & - & $\mathbf{v}$ & - & - & $\mathbf{v}$ & - & + \\
\hline \multicolumn{8}{|l|}{ Acid production from } \\
\hline Glucose & + & + & + & + & + & + & + \\
\hline Sucrose & + & + & - & - & + & + & + \\
\hline Mannitol & + & $\mathbf{v}$ & + & + & + & + & + \\
\hline Inositol & - & $\mathbf{v}$ & - & - & $\mathbf{v}$ & + & - \\
\hline D-Arabinose & - & - & - & - & - & + & - \\
\hline Cellobiose & + & + & + & + & + & + & + \\
\hline Melibiose & + & $\mathbf{v}$ & + & + & $\mathrm{v}$ & + & + \\
\hline Lactose & - & $\mathbf{v}$ & $\mathbf{v}$ & w & $\mathbf{v}$ & $\mathbf{w}$ & + \\
\hline \multicolumn{8}{|l|}{ Utilization as sole carbon source } \\
\hline$\beta$-Hydroxybutyrate & - & + & - & - & - & - & - \\
\hline Glcuose & + & + & + & + & + & + & + \\
\hline Mannitol & + & $\mathbf{v}$ & + & + & + & + & + \\
\hline Galactose & + & + & + & + & $\mathbf{v}$ & + & + \\
\hline Mannose & + & $\mathbf{v}$ & $\mathbf{v}$ & - & $\mathbf{v}$ & + & $\mathbf{v}$ \\
\hline L-Rhamnose & - & $\mathbf{v}$ & - & - & $\mathbf{v}$ & - & $\mathrm{v}$ \\
\hline Glycerol & + & $\mathbf{v}$ & $\mathbf{v}$ & - & $v$ & $\mathbf{v}$ & + \\
\hline Inositol & + & $\mathbf{v}$ & - & - & $\mathrm{v}$ & + & - \\
\hline Trehalose & + & + & - & + & $\mathrm{v}$ & - & - \\
\hline Dulcitol & - & - & - & - & - & - & + \\
\hline Tartrate & - & - & - & - & - & - & + \\
\hline Acetate & + & + & $\mathbf{v}$ & - & $\mathbf{v}$ & - & - \\
\hline Citrate & $\mathbf{v}$ & + & + & - & $\mathbf{v}$ & - & + \\
\hline
\end{tabular}

${ }^{a}$ All strains were positive for glucose fermentation and nitrogenase and were negative for Gram stain, swarming, pigmentation and luminescence

$b+$, positive; - , negative; $w$, weakly positive; $v$, variable between strains

c 2,4-diamino-6,7-diisopropylpteridine (phosphate) 
The strains included in group I were plump, straight rods. They accumulated PHB as an intracellular product and produced lecithinase. They utilized glucose, mannose, and glycerol but not $\beta$-hydroxybutyrate as the sole carbon sources. Gas was not produced during glucose fermentation. These strains could be assigned to the genus Photobacterium [2]. They were not luminous; however, this cannot exclude them from the genus because bioluminescence is no longer treated as a generic-key characteristic of Photobacterium [2]. Inclusion of nitrogen-fixing strains into the genus Photobacterium requires a redefinition of the genus because the current definition of Photobacterium states that no species fix $\mathrm{N}_{2}$ [2]. Strains belonging to this group have been isolated from sediment and eelgrass roots but not from seawater.

Group II contained strains that were able to accumulate PHB and utilize $\beta$-hydroxybutyrate as the sole carbon source. All strains included in this group were positive in oxidase and catalase reactions, and they did not produce gas during glucose fermentation. This group could be placed into the genus Vibrio [3]. All strains included in this group were isolated from eelgrass roots; none of these bacteria was isolated from samples of sediment or seawater.

Strains that could neither accumulate appreciable amounts of PHB nor utilize $\beta$-hydroxybutyrate were placed into the other five groups. Groups III, IV, V, and VI contained strains that produced acid but no gas during the fermentation of glucose. All these groups could also be assigned to the genus Vibrio. Groups III and IV contained strains that produced agarase but did not produce acid from sucrose. They might represent new species of the genus Vibrio because all recognized Vibrio species lack agarase activity. The strains included in group III liquefied agar. When the strains were streaked on PY agar plates and grown at $25^{\circ} \mathrm{C}$, deep holes were formed by the colonies in a few days. The agar in the plates was completely liquefied after incubation for 1-2 months. Some strains belonging to this group have been demonstrated to fix nitrogen anaerobically using agar as the sole carbon source [33]. Strains included in this group were isolated from either sediment or seawater, and none of them was isolated from eelgrass roots. Group IV contained strains that softened but did not liquefy agar. Colonies on PY-A plates were circular and were surrounded by shallow depressions; their agarase reaction was confirmed using the iodine test [1]. All strains included in group IV utilized trehalose and they could neither hydrolyze gelatin nor utilize citrate. These characteristics clearly distinguished them from group III. This group and groups V-VII were isolated from all the present samples, including seawater, sediment, and eelgrass roots.

Group $\mathrm{V}$ included the majority of the nitrogen-fixing isolates. The strains produced oxidase, amylase, and DNAse, but not agarase. Most of the strains also hydrolyzed gelatin. This group could be further divided into several subgroups because so many characteristics among the group were variable. Group VI included strains that were oxidase-negative. Acid production from D-Arabinose distinguished this group from all the other groups. All strains included in this group did not produce DNAse, amylase, lipase, and gelatinase. They did not utilize acetate and citrate as the sole carbon sources. These strains might represent a new species of Vibrio because only two oxidase-negative species are included in this genus [3], neither of which has been reported to produce nitrogenase. Vibrio diazotrophicus [12] and Vibrio natriegens [40] are 
the only two recognized species of Vibrio capable of fixing $\mathrm{N}_{2}$. Of the two species, the former can be included in group $\mathrm{V}$ and the latter is similar to the strains of group II. The Vibrio-like, nitrogen-fixing bacterium described in our previous report [32] can also be included in group II.

The strains included in group VII contained curved rods that produced not only acid but also gas during the fermentation of glucose. Catalase and oxidase were negative. They utilized dulcitol and tartrate as sole carbon sources. Amylase and lipase (Tween 80 hydrolysis) were not produced. At present, this group cannot be identified to the generic level. The strains included in this group either represent a new genus of the family Vibrionaceae or they are new members of the genus Vibrio [34].

Members of the halophilic, facultatively anaerobic bacteria comprise one of the predominant bacterial groups in many marine habitats. Some of them are known as pathogens of humans [4] or marine animals $[9,13,31]$. Their symbiotic relationship with luminous marine fishes has also received considerable attention $[29,30]$. The present results, as well as those of others $[10,40]$, indicate that halophilic, facultatively anaerobic bacteria may also be important in providing ammonium nitrogen into estuarine and coastal environments.

\section{References}

1. Agbo JAC, Moss MO (1979) The isolation and characterization of agarolytic bacteria from a lowland river. J Gen Microbiol 115:355-368

2. Baumann P, Baumann L (1984) Genus II Photobacterium Beijerinck 1889, 401 AL. In: Krieg NR (ed) Bergey's manual of systematic bacteriology, vol. 1. Williams and Wilkins Co, Baltimore, pp 539-545

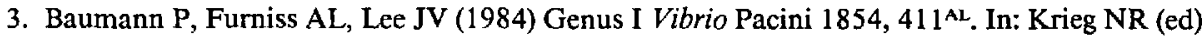
Bergey's manual of systematic bacteriology, vol. 1. Williams and Wilkins Co, Baltimore, pp 518-538

4. Blake PA, Weaver RE, Hollis DG (1980) Diseases of humans (other than cholera) caused by vibrios. Ann Rev Microbiol 34:341-367

5. Capone DG, Budin JM (1982) Nitrogen fixation associated with rinsed roots and rhizomes of the eelgrass Zostera marina. Plant Physiol 70:1601-1604

6. Capone DG, Taylor BF (1980) $\mathrm{N}_{2}$ fixation in the Thizosphere of Thalassia testudinum. Can J Microbiol 26:998-1005

7. Cochran WG (1950) Estimation of bacterial densities by means of the "most probable number." Biometrics 6:105-116

8. Dicker HJ, Smith DW (1980) Enumeration and relative importance of acetylene-reducing (nitrogen-fixing) bacteria in a Delaware salt marsh. Appl Environ Microbiol 39:1019-1025

9. Egidius E, Wilk R, Andersen K, Hoff KA, Hjeltnes B (1986) Vibrio salmonicida sp. nov., a new fish pathogen. Int J Syst Bacteriol 36:518-520

10. Guerinot ML, Colwell RR (1985) Enumeration, isolation, and characterization of $\mathrm{N}_{2}$-fixing bacteria from seawater. Appl Environ Microbiol 50:350-355

11. Guerinot ML, Patriquin DG (1981) The association of $\mathrm{N}_{2}$-fixing bacteria with sea urchins. Mar Biol 62:197-207

12. Guerinot ML, West PA, Lee JV, Colwell RR (1982) Vibrio diazotrophicus sp. nov, a marine nitrogen-fixing bacterium. Int J Syst Bacteriol 32:350-357

13. Hada HS, West PA, Lee JV, Stemmler J, Colwell RR (1984) Vibrio tubiashii sp. nov., a pathogen of bivalve mollusks. Int J Syst Bacteriol 34:1-4

14. Haines JR, Atlas RM, Griffiths RP, Morita RY (1981) Denitrification and nitrogen fixation in Alaskan continental shelf sediments. Appl Environ Microbiol 41:412-421 
15. Hicks BJ, Silvester WB (1985) Nitrogen fixation associated with the New Zealand mangrove [Avicennia marina (Forsk) Vierh var resinifera (Forst f) Bakh]. Appl Environ Microbiol 49: 955-959

16. Jones K (1982) Nitrogen fixation in the temperate estuarine intertidal sediments of the River Lune. Limnol Oceanogr 27:455-460

17. Jones KL, Rhodes-Roberts ME (1980) Physiological properties of nitrogen-scavenging bacteria from the marine environment. J Appl Bacteriol 49:421-433

18. Lindberg $T$, Granhall $U$ (1984) Isolation and characterization of dinitrogen-fixing bacteria from the rhizosphere of temperate cereals and forage grasses. Appl Environ Microbiol 48: 683-689

19. Martinez L, Silver MW, King JM, Alldredge AL (1983) Nitrogen fixation by floating diatom mats: A source of new nitrogen to oligotrophic ocean waters. Science 221:152-154

20. Maruyama Y, Suzuki T, Otobe K (1974) Nitrogen fixation in the marine environment: The effect of organic substrates on acetylene reduction. In: Colwell RR, Morita RY (eds) Effect of the environment on microbial activities. University Park Press, Baltimore, pp 341-353

21. Maruyama $Y$, Taga N, Matsuda O (1970) Distribution of nitrogen-fixing bacteria in the central Pacific Ocean. J Oceanogr Soc (Jpn) 26:360-366

22. McClung CR, Patriquin DG, Davis RE (1983) Campylobacter nitrofigilis sp. nov., a nitrogenfixing bacterium associated with roots of Spartina alterniflora Loisel. Int J Syst Bacteriol 33: $605-612$

23. Nedwell DB, Azni bin Abdul Aziz S (1980) Heterotrophic nitrogen fixation in an intertidal saltmarsh sediment. Estuarine Coastal Mar Sci 10:699-702

24. Paerl HW, Carlton RG (1988) Control of nitrogen fixation by oxygen depletion in surfaceassociated microzones. Nature 332:260-262

25. Paerl HW, Prufert LE (1987) Oxygen-poor microzones as potential sites of microbial $\mathrm{N}_{2}$ fixation in nitrogen-depleted aerobic marine waters. Appl Environ Microbiol 53:1078-1087

26. Patriquin DG, Denike D (1978) In situ acetylene reduction assay of nitrogenase activity associated with the emergent halophyte Spartina alterniflora Loisel: Methodological problems. Aqua Bot 4:211-226

27. Patriquin D, Knowles $R$ (1972) Nitrogen fixation in the rhizosphere of marine angiosperms. Mar Biol 16:49-58

28. Patriquin DG, McClung CR (1978) Nitrogen accretion, and the nature and possible significance of $\mathrm{N}_{2}$ fixation (acetylene reduction) in a Nova Scotian Spartina alterniflora stand. Mar Biol 47:227-242

29. Reichelt JL, Nealson KH, Hastings JW (1977) The specificity of symbiosis: Pony fish and luminescent bacteria. Arch Microbiol 112:157-161

30. Ruby EG, Morin JG (1978) Specificity of symbiosis between deep-sea fishes and psychrotrophic luminous bacteria. Deep Sea Res 25:161-167

31. Schiewe MH, Trust TJ, Crosa JH (1981) Vibrio ordalii sp. nov. - A causative agent of vibriosis in fish. Curr Microbiol 6:343-348

32. Shieh WY, Simidu U, Maruyama Y (1987) Isolation of a nitrogen-fixing Vibrio species from the roots of eelgrass (Zostera marina). J Gen Appl Microbiol 33:321-330

33. Shieh WY, Simidu U, Maruyama Y (1988) Nitrogen fixation by marine agar-degrading bacteria. J Gen Microbiol 134:1821-1825

34. Shich WY, Simidu U, Maruyama Y (1988) New marine nitrogen-fixing bacteria isolated from an eelgrass (Zostera marina) bed. Can J Microbiol 34:886-890

35. Shieh WY, Simidu U, Maruyama Y (1989) Nitrogenase activity of heterotrophic bacteria associated with the roots of eelgrass (Zostera marina). Nippon Suisan Gakkaishi (formerly Bull Japan Soc Sci Fish) 55:853-857

36. Smith GW, Hayasaka SS (1982) Nitrogenase activity associated with Zostera marina from a North Carolina estuary. Can J Microbiol 28:448-451

37. Stewart WDP (1971) Nitrogen fixation in the sea. In: Costlow JD (ed) Fertility of the sea. Gordon and Breach Science Publishers, London, pp 537-564

38. Watanabe I, Barraquio WL (1979) Low levels of fixcd nitrogen required for isolation of freeliving $\mathrm{N}_{2}$-fixing organisms from rice roots. Nature (London) 277:565-566 
39. Waterbury JB, Calloway CB, Turner RD (1983) A cellulolytic nitrogen-fixing bacterium cultured from the gland of Deshayes in shipworms (Bivalvia: Teredinidae). Science 221:14011403

40. West PA, Brayton PR, Twilley RR, Bryant TN, Colwell RR (1985) Numerical taxonomy of nitrogen-fixing "decarboxylase-negative" Vibrio species isolated from aquatic environments. Int J Syst Bacteriol 35:198-205

41. Wiebe WJ, Johannes RE, Webb KL (1975) Nitrogen fixation in a coral reef community. Science 188:257-259

42. Wynn-Williams DD, Rhodes ME (1974) Nitrogen fixation in seawater. J Appl Bacteriol 37 : 203-216

43. Zuberer DA, Silver WS (1974) Mangrove-associated nitrogen fixation. In: Walsh GE, Snedaker $\mathrm{SC}$, Teas HJ (eds) The biology and management of mangroves. University of Florida, Gainesville

44. Zuberer DA, Silver WS (1978) Biological dinitrogen fixation (acetylene reduction) associated with Florida mangroves. Appl Environ Microbiol 35:567-575 